\title{
Dimensions of Early Childhood Character Education Based on Multicultural and Community Local Wisdom
}

\section{Harun}

Lecturer, Yogyakarta State University, Yogyakarta, Indonesia, harun@ uny.ac.id

\section{Amat Jaedun}

Lecturer, Yogyakarta State University, Yogyakarta, Indonesia,a_jaedun@yahoo.com

\section{Sudaryanti}

Lecturer, Yogyakarta State University, Yogyakarta, Indonesia, sudaryanti@uny.ac.id

\author{
Abdul Manaf \\ Doctoral student in Yogyakarta State University, Indonesia, \\ abdulmanaf.2017@student.uny.ac.id
}

The purpose of this study was to determine the dimensions of early childhood character education based on multicultural and local wisdom. The location of the research is in the Central Java Province, specially the Ex Surakarta Residency and Ex Kedu Residency. Research subjects were 430 children from 24 Early Childhood Education Institutions (PAUD). The research method used is quantitative with the LISREL program tool. The analytical tool used is structural equations modeling to examine the dimensions of early childhood character education, measurement model analysis, and structural model analysis of early childhood character education. The hypothesized dimension of character education has four dimensions with each having four indicators, apparently after being confirmed empirical data there are two indicators that fall, namely indicators of sincerity acting in the dimensions of deity and indicators of discipline in the dimension of oneself. Therefore the dimension of deity only has indicator of belief, worship, and ethical values. The self dimension has indicators of honesty, responsibility, and independence. The dimension of fellow human still have four indicators, namely rights and obligations, obeying the law, appreciating the work of others, and being polite to anyone. The environmental dimension also has four indicators, national spirit, love for the country, communicative, and caring for the environment.

Keywords: education, character, early childhood, multicultural, local wisdom, community

Citation: Harun, Jaedun, A., Sudaryanti, \& Manaf, A. (2020). Dimensions of Early Childhood Character Education Based on Multicultural and Community Local Wisdom. International Journal of Instruction, 13(2), 365-380. https://doi.org/10.29333/iji.2020.13225a 


\section{INTRODUCTION}

School, in essence, is not just a place of "transfer of knowledge". As stated by AlMusanna (2012) schools are not merely places where teachers convey knowledge through various subjects. Schools are institutions that seek and value-oriented enterprise processes. Furthermore, Al-Musanna states, that the organization of a school system in itself is a moral effort (enterprise moral).

In the concept of education policy in Indonesia, Hanum (2009) states that there are three main pillars of the identity of the Indonesian nation that must not be undermined in any way. First, Indonesia is a nationality. Second, Indonesia is a country that was proclaimed on August 17, 1945. Third, Indonesia is a region.

This concept must be the basis of national education. National education is developed with the principle of supporting and giving space to differences in each region and educational institutions. However, all cultural differences in educational institutions must be bound by the mindset, actions, and character that reflect Indonesian people.

Associated with the character Çağatay (2009); Khoury (2017), terminologically the term character is related to positive behavior or virtue. In the context of the character, AlGhazali (2000) character is closer to morals. According to Lickona (1991), Stedje (2010), Fleeson (2014), Woodbury and Lapsley (2016), Lerner (2017), Nucci (2017), Goodman (2018) characters have characteristics that are relevant to morals. Curriculum Redesign Report on Character Qualities (2015) characters include attitudes, behaviors, dispositions, mindset, personality, temperament, social and emotional values or skills. So the character is related to behavior, morals, character that is inherent in everyone.

Character building is one of the national education purposes. Article 1 (pasal 1) of the 2003 national education System Law states that among the objectives of national education is to develop the potential of students to have intelligence, personality, and noble character. Furthermore, in Article 3 (pasal 3) it is stated that the aim of national education is to develop the potential of students to become human beings who believe and fear God Almighty, have a noble character, are healthy, knowledgeable, capable, creative, independent, and become responsible citizens (Husaini, 2015).

Arifudin (2007) states that there are five dimensions of multicultural education that are interrelated. First; integrating various cultures and groups to illustrate fundamental concepts, generalizations, and theories in subjects. Second; brings children to understand the cultural implications of a subject. Third; adjusting teaching methods by means of children's learning in order to facilitate academic achievement. Fourth; identify the characteristics of the child's race and determine the method of teaching. Fifth; train groups to participate in various activities, interact with all children and staff of different races and ethnicities to create an academic culture. Schools that are successful in implementing multicultural education if the school has an award for each group, respect while creating a sense of togetherness and ownership (Bakerman\& Tatar, 2009). Multicultural education must include good teaching and good education (Payne, 1984). Three aspects of multicultural education are a multicultural perspective on the 
curriculum, education for intercultural understanding and ethnic studies (Matthews \& Scott, 1981).

Multicultural education is one way to deal with racism (Kang, 2010), and reduce social inequality (Pittman, 2009), Piland and Barnard (1996). In multicultural education differences in culture, language, gender, class, ethnicity, and race are eliminated (Holm and Londen, 2010). Multicultural education is the process of cultivating values and ways of life respecting, sincere, and tolerant of the diversity of cultures that live in the midst of a pluralistic society. Multicultural education must include matters relating to tolerance, ethnocultural and religious differences, the dangers of discrimination, conflict resolution and mediation, human rights, democracy and plurality, universal humanity, and other relevant subjects that lead to the formation of civil society that loves peace and respects difference.

The accuracy of the selection of strategies will provide optimal results in shaping children of character. Meanwhile, Harun (2017) details the character values that must be built for early childhood including honest; express the contents of the heart; not hurt each other; mutual help; return goods in their place; alternately speaking; give friends the opinion; queued; mutual respect; speak well and politely; listen to other people speak; modeling behavior. Thus, efforts to develop the character education dimension as a strategy for implementing multicultural based character education are very important to do in PAUD. The development of the principle of multicultural based character value education is integrative, compact, and consistent. Integrative means integrating multicultural character education into all campus programs and activities. Compact means that all components of education have the same attitudes and views in implementing multicultural based character education. Consistent means that all components of education have consistent attitudes and views in implementing multicultural based character education in PAUD.

Planting character values is difficult. Therefore, at the PAUD level, a number of main character values are selected which are summarized from the points of Graduate Competence Stanndar (SKL) PAUD (Minister of Education Regulation Number 32 of 2010a) and SK/KD (Minister of Education Regulation Number 22 of 2010b). The purpose of this study was to determine the dimensions of multicultural character education and local wisdom of the community. The question of the problems examined in this study are:

(1) How are the constructs of the dimension of early childhood character education in relation to self?

(2) How are the constructs of the dimension of early childhood character education in relation to deity?

(3) How are the constructs of the dimension of early childhood character education in relation to fellow human?

How is the construct of the dimension of early childhood character education in relation to the environment? 


\section{METHOD}

This research uses a quantitative approach. The design of this study examines the types of multicultural character education and local wisdom for early childhood in PAUD schools.

\section{Participants}

Research locations in the Central Java Province, specially the Ex Surakarta Residency and Ex Kedu Residency. The research subjects were 430 children from 24 PAUD institutions.

\section{The Technique of Data Collection}

The instrument of data collection uses questionnaires, interview guides and observation sheets. The three tools are to collect data on dimensions of multicultural character-based education for early childhood and their impact on early childhood development.

\section{Research variable}

Hypothetic dimensions character education as latent variable consists of four subvariables: First; character in relation to deity; which consists of sub-variables: beliefs/creeds; diligently worship; sincerity of action; virtue (akhlakul karimah). Second; character in relation to oneself consists of: honesty; discipline; responsible; and independence. Third; character in relation to fellow human consisting of sub-variables: aware of the rights and obligations of self and others; obey legal/customary rules and respect the work and achievements of others. Fourth; The character of the relationship with the environment consists of sub-variables: polite behavior to fellow people; the spirit of nationality; love the country; friendly/communicative, and care for the environment

\section{The technique of data analysis}

The quantitative data obtained were analyzed using the LISREL program (Ghazali and Fuad, 2005). This program was chosen because it accommodates exogenous latent variables and endogenous latent variables; is an integrated approach between factor analysis, structural models, and path analysis; and the variables in the quantitative data of this study consist of two groups or models, namely the measurement model and structural equation models can be observed and can be measured.

\section{FINDINGS}

\section{Distribution of Respondent}

The research respondents came from 2 Districts (KAB) and 2 Municipalities (KOTA) with proportions between regions of $\pm 25 \%$. The proportion of respondents who came from Magelang Regency was $27.91 \%$, Magelang as much as $27.67 \%$, Sukoharjo Regency as much as $23.26 \%$, and Surakarta City with $21.16 \%$ (Figure 1). 


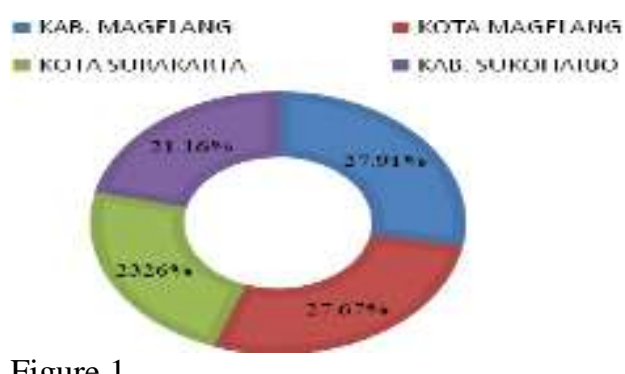

Figure 1

The Proportion of Distribution of Respondents from 4 Regencies/City

Distribution of respondents based on sub-district area consisted of Srumbung Subdistrict as many as 120 children, South Magelang Subdistrict as many as 119 people, Laweyan Subdistrict as many as 81 children, Banjarsari Subdistrict as many as 19 children, Baki Subdistrict as many as 62 children, Grogol Subdistrict as many as 14 children, and Mojolaban District as many as 15 children (Figure 2).

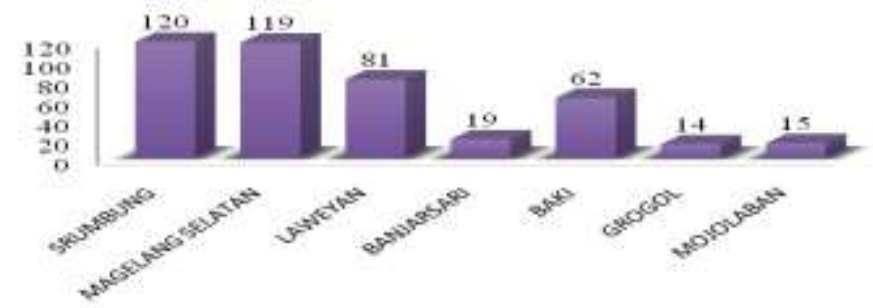

Figure 2

Proportion of Respondents per District Distribution

\section{Results of Character Education Assessment}

Results of Character Education Assessment The frequency distribution of the results of character education assessment consisted of the lowest score of 104, the highest score of 204 , the range of 100, and the formation of 10 classes of a classified class frequency distribution (Table 1).

Table 1

Classified Frequency Distribution of Early Childhood Character Education Data

\begin{tabular}{lccc}
\hline Class Interval & Frequency & Percent & Cumulative Percent \\
\hline $102.40-112.71$ & 1 & 0.23 & 0.23 \\
$112.72-123.03$ & 8 & 1.86 & 2.09 \\
$123.04-133.35$ & 26 & 6.05 & 8.14 \\
$133.36-143.67$ & 27 & 6.28 & 14.42 \\
$143.68-153.99$ & 50 & 11.63 & 26.05 \\
$154.00-164.31$ & 70 & 16.28 & 42.33 \\
$164.32-174.63$ & 63 & 14.65 & 56.98 \\
$174.64-184.95$ & 73 & 16.98 & 73.95 \\
$184.96-195.26$ & 77 & 17.91 & 91.86 \\
$195.27-205.59$ & 35 & 8.14 & 100 \\
\hline
\end{tabular}

Note: The frequency distribution of the results of character education assessment. 
The majority of early childhood education in Central Java is included in the score category between 184.96 and 195.26 , or $17.91 \%$. If the interval class numbers 1 to 10 are drawn in the form of line charts (Figure 3), then there are 368 children who score above 144

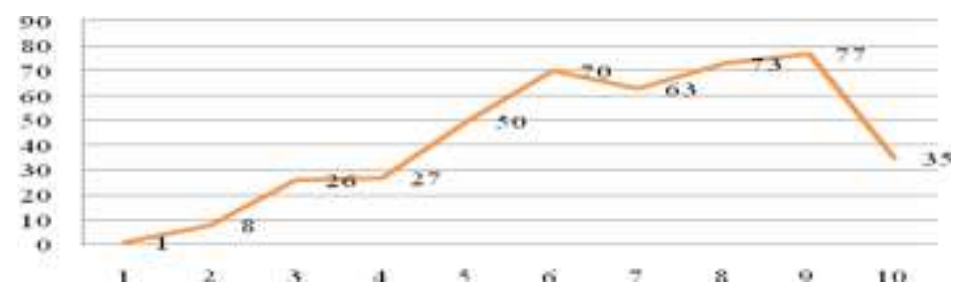

Figure 3

Outline of Achievement of Early Childhood Character Education Line Charts

\section{Results of First Oder Confirmatory Factor Analysis}

\section{Latent variable SELF}

The dimension of a child's relationship with oneself have twelve statements. Based on the output of standardized factor loading, indicators D1, D2, D3, D4, D5, and D6 < 0.50 , while indicators D7, D8, D9, D10, D11, and D12>0.50 (Figure 4a). Thus indicators D1, D2, D3, D4, D5, and D6 are not included in the analysis of first-order confirmatory factor analysis. The finding of test data 1 shows the value of Chi-square, RMSEA, p-value and GFI not fulfilling the criteria suggested by Browne and Cudeck (1993), Joreskorg and Sorbom (2003), and Schermelleh-Engel, Moosbrugger and Mueler (2003) so that they do not meet the model suitability (poor fit). Test result 2 (Figure 4b) has fulfilled the good fit requirements. The results of the comparison of the first and second model match tests of the SELF dimension show significant differences and changes (Table 2).

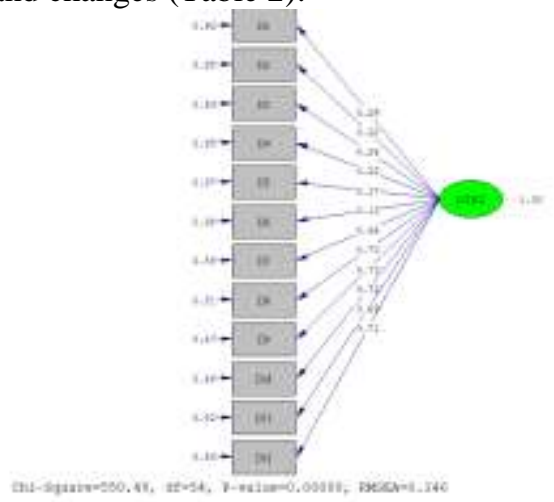

Figure 4 (a)

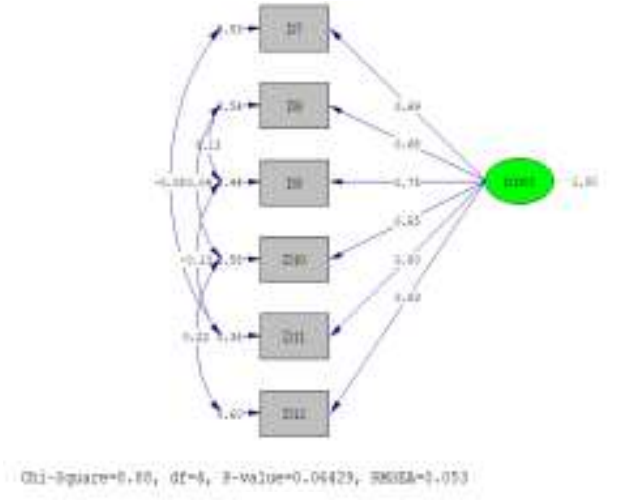

(b

(a). Standardized Loading Factor Indicator D1-D12 SELF (עIII) Test Initial Model; (b) Standardized Loading Factor Indicator D7-D12 Dimensions SELF Respecification 
Table 2

Concise Size of GoF Latent Variable SELF Early and Respecific Test Models

\begin{tabular}{lllc}
\hline Size of GoF & Match Criteria & Findings of Data U1 & Findings of Data U2 \\
\hline Chi-Square & Small value & 550.49 & 8.88 \\
$\mathrm{p}$ & $\mathrm{p}>0.05$ & $(\mathrm{p}=0.00)$ & $(\mathrm{p}=0.06)$ \\
RMSEA & $\mathrm{RMSEA} \leq 0.05$ & 0.14 & 0.05 \\
NFI & $\mathrm{NFI} \geq 0.90$ & 0.78 & 0.99 \\
NNFI & $\mathrm{NNFI} \geq 0.90$ & 0.75 & 0.99 \\
CFI & $\mathrm{CFI} \geq 0.90$ & 0.79 & 1.00 \\
IFI & $\mathrm{IFI} \geq 0.90$ & 0.79 & 1.00 \\
RFI & $\mathrm{RFI} \geq 0.90$ & 0.73 & 0.98 \\
CN & $\mathrm{CN} \geq 200$ & 64.18 & 642.75 \\
GFI & $\mathrm{GFI} \geq 0.90$ & 0.78 & 0.99 \\
AGFI & $\mathrm{AGFI} \geq 0.90$ & 0.68 & 0.95 \\
\hline
\end{tabular}

Note: GoF = Goodness of Fit Latent Variable DEITY

Latent variable relationship between children and God has twelve statements. Based on the output of standardized factor loading, the indicator T4 is $<0.50$, while indicators $\mathrm{T} 1$, T2, T3, T5, T6, T7, T8, T9, T10, T11, and T12 > 0.50 (Figure 5a). Thus the T4 indicator is not included in the analysis of first-order confirmatory factor analysis. The finding of test data 1 shows the value of Chi-square, RMSEA, p-value and GFI not fulfilling the criteria suggested by Browne and Cudeck (1993), Joreskorg and Sorbom (2003), and Schermelleh-Engel, Moosbrugger and Mueler (2003) so that they do not meet the model suitability (poor fit). Re-analysis was carried out on the dimensions of the relationship between the child and his deity by having eleven indicators. Test result 2 (Figure 5b) meets the requirements of the model fit (good fit). The results of the comparison of the first and second model match tests of the DEITY dimension show significant differences and changes (Table 3 ).

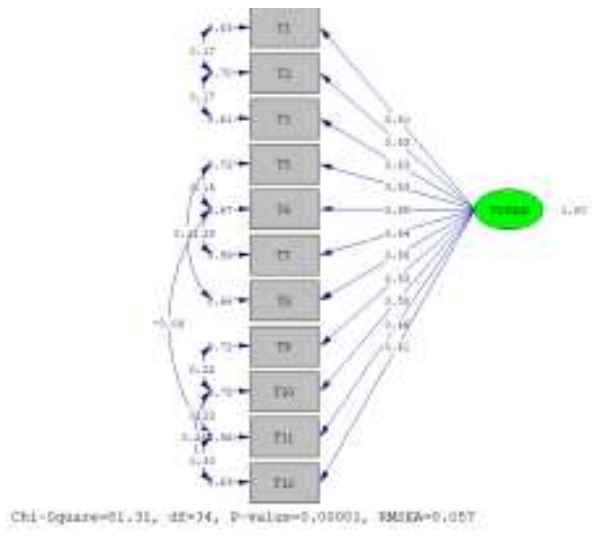

(a)

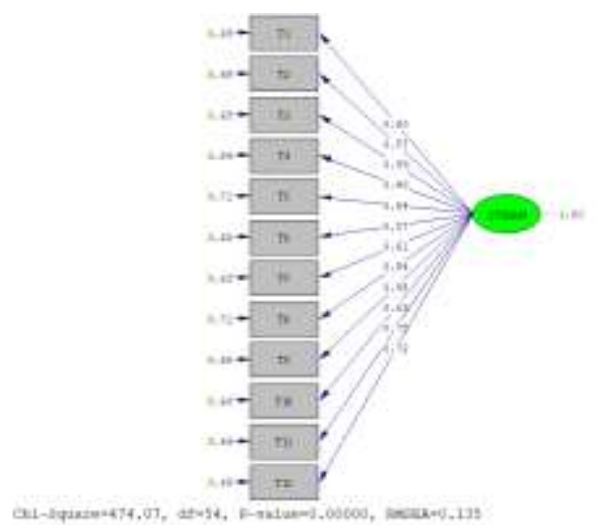

(b)

Figure 5

(a). Standardized Loading Factor Indicator T1-T12 Dimension DEITY (KETUHANAN)

Early Model Test; (b) Standardized Loading Factor Indicators T1-T3, T5-T12 Dimensions Deity Respecification 
Table 3

Concise GoF Size Latent Variable DEITY Early and Respecific Test Models

\begin{tabular}{lclc}
\hline Size of GoF & Match Criteria & Findings of Data U1 & Findings of Data U2 \\
\hline Chi-Square & Small value & 474.07 & 81.31 \\
$\mathrm{p}$ & $\mathrm{p}>0.05$ & $(\mathrm{p}=0.00)$ & $(\mathrm{p}=0.00)$ \\
RMSEA & RMSEA $\leq 0.05$ & 0.13 & 0.057 \\
NFI & $\mathrm{NFI} \geq 0.90$ & 0.88 & 0.98 \\
NNFI & $\mathrm{NNFI} \geq 0.90$ & 0.86 & 0.98 \\
CFI & $\mathrm{CFI} \geq 0.90$ & 0.89 & 0.99 \\
IFI & $\mathrm{IFI} \geq 0.90$ & 0.89 & 0.99 \\
RFI & $\mathrm{RFI} \geq 0.90$ & 0.85 & 0.96 \\
CN & $\mathrm{CN} \geq 200$ & 74.19 & 296.10 \\
GFI & $\mathrm{GFI} \geq 0.90$ & 0.80 & 0.96 \\
AGFI & AGFI $\geq 0.90$ & 0.71 & 0.92 \\
\hline
\end{tabular}

Note: GoF = Goodness of Fit Latent Variable Fellow Human

Latent variables of the relationship between children and fellow human have thirteen items of statements. Based on the output standardized factor loading, indicators S1, S2, S3, S4, S5 and S6 <0.50, while indicators S7, S8, S9, S10, S11, S12, and S13>0.50 (Figure 6a). Thus indicators of S1, S2, S3, S4, S5, and S6 are not included in the analysis of first-order confirmatory factor analysis. The finding of test data 1 shows the value of Chi-square, RMSEA, p-value and GFI not fulfilling the criteria suggested by Browne and Cudeck (1993), Joreskorg and Sorbom (2003) and Schermelleh-Engel, Moosbrugger and Mueler (2003) so that they do not meet the model suitability (poor fit). Re-analysis was carried out on the dimensions of child relationships with fellow humans by having seven indicators. Test result 2 (Figure 6b) has met the good fit requirements. The results of the comparison of the first and second model match tests from the FELLOW HUMAN dimension show striking differences and changes (Table 4).

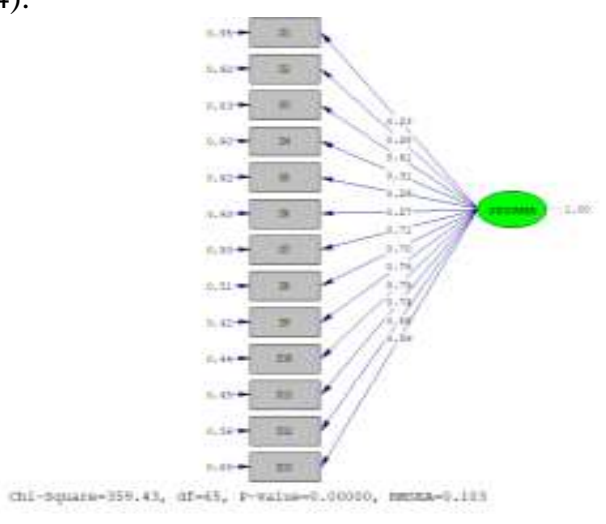

(a)

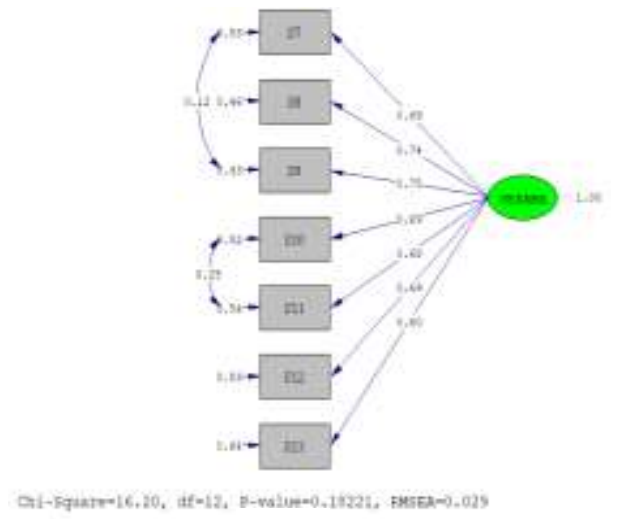

(b)

Figure 6

(a). Standardized Loading Factor Indicator S1-S13 Dimension Fellow Human (Sesama Manusia) Initial Model; (b) Standardized Loading Factor Indicator S7-S13 Dimension of Human Fellow Respecifications 
Table 4

Concise Size of GoF Latent Variable Fellow Human Early and Respecific Test Models

\begin{tabular}{lcll}
\hline Size of GoF & Match Criteria & Findings of Data U1 & Findings of Data U2 \\
\hline Chi-Square & Small value & 395.43 & 16.20 \\
$\mathrm{p}$ & $\mathrm{p}>0.05$ & $(\mathrm{p}=0.00)$ & $(\mathrm{p}=0.18)$ \\
RMSEA & RMSEA $\leq 0.05$ & 0.103 & 0.029 \\
NFI & NFI $\geq 0.90$ & 0.89 & 0.99 \\
NNFI & NNFI $\geq 0.90$ & 0.89 & 1.00 \\
CFI & CFI $\geq 0.90$ & 0.91 & 1.00 \\
IFI & IFI $\geq 0.90$ & 0.91 & 1.00 \\
RFI & RFI $\geq 0.90$ & 0.87 & 0.99 \\
CN & CN $\geq 200$ & 113.70 & 695.25 \\
GFI & GFI $\geq 0.90$ & 0.86 & 0.98 \\
AGFI & AGFI $\geq 0.90$ & 0.80 & 0.96 \\
\hline
\end{tabular}

Note: $\mathrm{GoF}=$ Goodness of Fit Latent Variable Environment

Latent variables of child relations with the surrounding environment have fourteen statements. Based on the output of standardized factor loading, indicators L1, L6, L7, L10, L11, and L14 < 0.50, while indicators L2, L3, L4, L5, L8, L9, L12, and L13>0.50 (Figure 7a). Thus the indicators L1, L6, L7, L10, L11, and L14 are not included in the analysis of first-order confirmatory factor analysis. The finding of test data 1 shows the value of Chi-square, RMSEA, p-value and GFI not fulfilling the criteria suggested by Browne and Cudeck (1993), Joreskorg and Sorbom (2003), and Schermelleh-Engel, Moosbrugger and Mueler (2003) so that they do not meet the model suitability (poor fit). Re-analysis was carried out on the dimensions of the child's relationship with the surrounding environment which had eight indicators. Test result 2 (Figure 7b) has met the good fit requirements. The results of the comparison of the first and second model compatibility tests from the ENVIRONMENT dimension show significant differences and changes (Table 5).

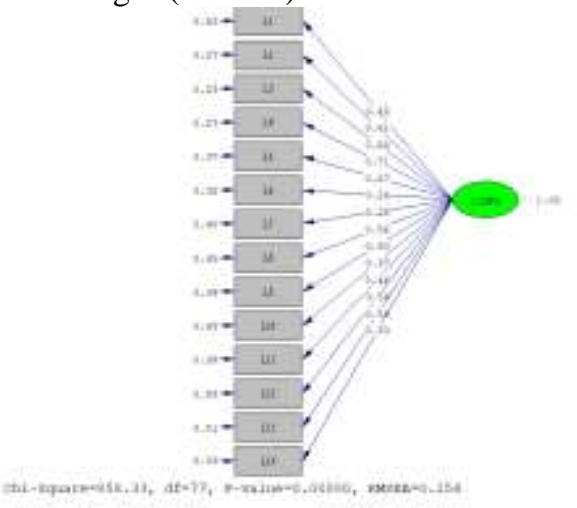

(a)

Figure 7

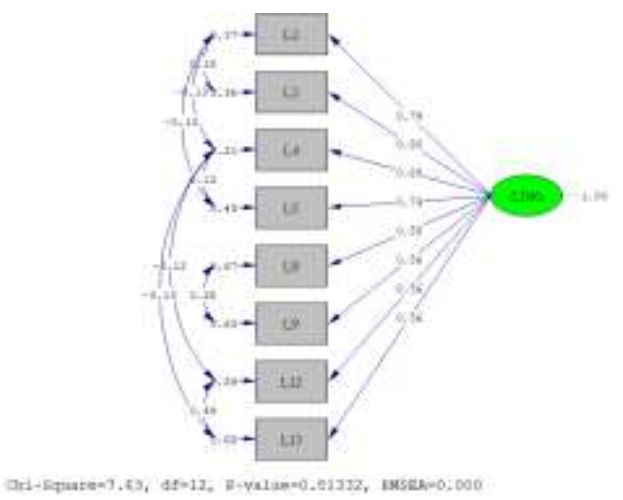

(b)

(a). Standardized Loading Factor Indicator L1-L14 Dimension Environment Initial Model; (b) Standardized Loading Factor Indicators L2-L13 Dimensions of Environmental (Lingkungan) Respecifications 
Table 5

Concise Size of GoF Latent Variable Environment Early and Respecific Test Models

\begin{tabular}{llll}
\hline Size of GoF & Match Criteria & Findings of Data U1 & Findings of Data U2 \\
\hline Chi-Square & Small value & 858.33 & 7.63 \\
$\mathrm{p}$ & $\mathrm{p}>0.05$ & $(\mathrm{p}=0.0)$ & $(\mathrm{p}=0.81)$ \\
RMSEA & RMSEA $\leq 0.05$ & 0.154 & 0.00 \\
NFI & $\mathrm{NFI} \geq 0.90$ & 0.86 & 1.00 \\
NNFI & NNFI $\geq 0.90$ & 0.85 & 1.00 \\
CFI & $\mathrm{CFI} \geq 0.90$ & 0.87 & 1.00 \\
IFI & IFI $\geq 0.90$ & 0.87 & 1.00 \\
RFI & RFI $\geq 0.90$ & 0.84 & 0.99 \\
CN & $\mathrm{CN} \geq 200$ & 55.37 & 1475.08 \\
GFI & GFI $\geq 0.90$ & 0.72 & 0.99 \\
AGFI & AGFI $\geq 0.90$ & 0.61 & 0.98 \\
\hline
\end{tabular}

Note: $\mathrm{GoF}=$ Goodness of Fit

\section{Compatibility of the whole PAUD character education model}

The results of the conformity test model for the whole PAUD character education model consisted of four sub-variable latents, SELF, DEITY, FELLOW HUMAN and ENVIRONMENT (Table 6).

Table 6

Findings of Research Data for Compatibility Test of the Overall Early Childhood Character Education Model

\begin{tabular}{lccl}
\hline Size of GoF & Match Criteria & Findings of Data & Match Level \\
\hline Chi-Square & Small value & 2.39 & Close fit \\
$\mathrm{p}$ & $\mathrm{p}>0.05$ & $(\mathrm{p}=0.30)$ & Close fit \\
RMSEA & RMSEA $\leq 0.05$ & 0.00 & Close fit \\
NFI & $\mathrm{NFI} \geq 0.90$ & 1.00 & Close fit \\
NNFI & $\mathrm{NNFI} \geq 0.90$ & 1.00 & Close fit \\
CFI & $\mathrm{CFI} \geq 0.90$ & 1.00 & Close fit \\
IFI & $\mathrm{IFI} \geq 0.90$ & 1.00 & Close fit \\
RFI & $\mathrm{RFI} \geq 0.90$ & 1.00 & Close fit \\
CN & $\mathrm{CN} \geq 200$ & 2841.99 & Close fit \\
GFI & $\mathrm{GFI} \geq 0.90$ & 1.00 & Close fit \\
AGFI & AGFI $\geq 0.90$ & 0.99 & Close fit \\
\hline
\end{tabular}

Note: $\mathrm{GoF}=$ Goodness of Fit

Based on Table 6, the values of Chi-square, RMSEA, p-value and GFI meet the criteria suggested by Browne and Cudeck (1993), Joreskorg and Sorbom (2003) and Schermelleh-Engel, Moosbrugger and Mueler (2003) so that they meet the model suit (good fit).

\section{Measurement Model Analysis}

Analysis of the measurement model consists of the validity and reliability of the measurement model. Evaluation of the validity of the measurement model based on the criteria of load factor loadings $t$-value $>1.96$, and the standardized factor loadings $\geq$ 
0.50. Based on output LISREL (Figure 8) concludes that the validity of all observed variables for each variable latent is good.

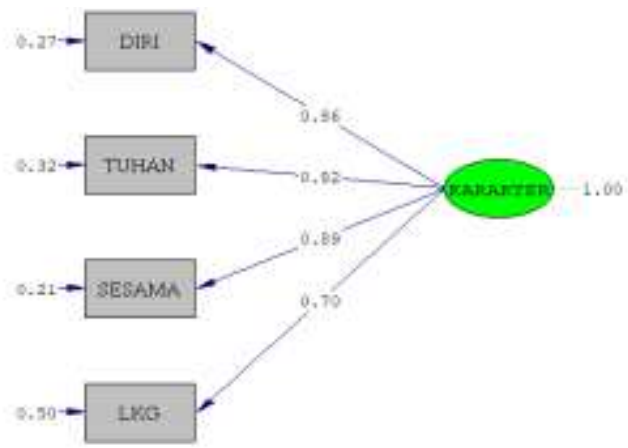

Chi-Square=I-39, de $=2, P-$ Value=0.49884, RMSEA=0+000

Figure 8

Standardized Loading Factor Indicator for LVS1-LVS4 Early Childhood Character Assessment Model. Self (Diri), Deity (Ketuhanan), Fellow Human (Sesama) and Environment $(\mathrm{Lkg})$, Character (Karakter)

Evaluation of reliability uses the composite reliability measure and variance extracted measure for each latent variable. Based on the results of calculations using the CR and VE formulas, the $C R$ value of 0.89 can meet the requirements because it is $\geq 0.70$, while the value of $\mathrm{VE}$ is 0.67 , also has fulfilled the requirements because of $\geq 0.50$. Thus it can be concluded that the reliability of the measurement model is very good.

\section{Results of Structural Model Analysis}

This analysis includes criteria for t-value $>1.96$, estimated coefficient value, and the coefficient of determination $\left(\mathrm{R}^{2}\right)$. The causal relationship between character and self, deity, fellow humans, and the environment has a significant relationship. Value of tvalue $>1.96$, estimated coefficient value $\geq 0.70$, determination coefficient value $\geq 0.50$.

\section{DISCUSSION}

This study discusses the dimensions of character education formed in early childhood based on the results of the above research, it can be stated that the dimensions of character education for early childhood based on multicultural and local wisdom in PAUD Central Java Province are very important to be developed in the current global era. In connection with character education, Lopes et al (2013) argued that character education is a system change approach to overcome the influence of children's cognition and behavior. Whereas Ugurlu (2014) states that character education is designed to instill social attitudes and positive behavior in a person, in order to encourage the development of social competence. Whereas Lickona (1999) argues that character education aims to foster virtue values in a person. Character education sets virtue values as the key to the goal of character education. The value of virtue in question is 
politeness, child piety, honesty, responsibility, respect, consideration, communication, and cooperation (Par, 2017). Related to the level of expression of love, integrity, compassion, and higher self-discipline (Jeynes, 2017). So that through multicultural and local-based character education makes researchers, lecturers or teachers to be able to know the character of early childhood in their relations with self, deity, human fellow, and environment. The four dimensions of character generated in early childhood character education meet the model fit criteria suggested by Browne and Cudeck (1993), Joreskorg and Sorbom (2003) and Schermelleh-Engel, Moosbrugger, and Mueler (2003).

The first dimension is the dimension of relations with oneself. This consists of four indicators, namely honesty, discipline, responsibility, and independence. The dimensions of a child's relationship with oneself have twelve statements. These results are in line with the social and emotional development of early childhood, meaning character education. In the context of this character, (Lickona, 1997) to be honest and responsible. The second dimension is the relationship with deity. This consists of four indicators namely belief/aqeedah, diligent worship, the sincerity of action and ethical values. The dimension of relations with deity has twelve statements. The third dimension is with fellow people. It consists of four indicators, namely rights and obligations, obeying the rules, respecting the work of others and the same polite behavior. The dimensions of relations with fellow-citizens have thirteen points of statement.

The fourth dimension is the relationship with the environment. It consists of four indicators, namely the spirit of nationalism, proportional love for the country, friendship/communicative and caring for the environment. The dimension of environmental relations has fourteen items of the statement. During the age of kindergarten, children can interact with other children, and with other people around them, such as exploring the environment and making peer group ties (Berk, 1989). This is a characteristic that is characterized in general normal children, and they are already able to learn to socialize themselves with a special cultural environment (Routh, 1980). Thus, early childhood education must be in a comfortable and pleasant environment. Berns (2004) states that the development and formation of a person's character are influenced by various factors including the environment.

Based on the results of the analysis of measurement validity (Figure 8), it is concluded that the validity of all observed variables for each of the latent variables is valid. Evaluation of reliability using composite reliability measure and variance extracted measure for each latent variable obtained CR value of 0.89 and VE value of 0.67 has met the requirements (Hair et al, 2010). Thus it can be concluded that the criteria for validity and reliability are fulfilled.

the causal relationship between character and self, god, equation, environment proved that there was a significant relationship with the $\mathrm{t}$-value $\geq 1,96$. this self, deity, human fellow, and environment means that these four dimensions have a very important influence on the development of the character of early childhood. The dimensions of relations with others have a very large influence on the development of the character of 
early childhood, namely $79 \%$. While the environmental dimension has a very small effect of $50 \%$.

\section{CONCLUSION}

The dimension of early childhood character education is hypothesized to have four dimensions, each dimension has four indicators, it turns out that after being confirmed by empirical data there are two indicators that do not meet the specified criteria namely sincerity indicator which is an indicator of character dimensions related to the relationship of deity and disciplinary indicators which is an indicator of the dimensions of character relating to relationships with oneself, so that the divine dimension only has three indicators namely the values of faith, worship, and ethics. While the dimensions of self have three indicators, namely honesty, responsibility, and independence. Dimensions of character related to fellow human still have four indicators namely rights and obligations, obeying the law, respecting the work of others, and being polite to anyone. While the dimensions of character related to relations with the environment also have four indicators namely the spirit of nationalism, patriotism, communicative, and environmental care. From the four dimensions of early childhood character education it is found that the factor loading values are the dimensions of the relationship with deity (0.82), the dimension of relationship with oneself (0.86), the dimension of relations with fellow humans (0.89), and the dimension with environmental relationships (0.70). Based on the specified factor loading value criteria, all dimensions of early childhood character education meet the criteria. The dimension of character education related to relationships with fellow humans has a large factor loading value, so that the inculcation of character values in early childhood in PAUD institutions in Central Java, specially in Ex Surakarta Residency and Ex Kedu Residency are already well implemented. In addition, character values related to relationships with fellow humans have begun to develop in early childhood. While the character dimensions related to the relationship with the environment have a small factor loading value, so the character values need to be increased again. Overall multicultural character-based early childhood education and local wisdom carried out at PAUD institutions have had a good impact on the cultivation of virtue values for early childhood.

Looking at the results of this study, it can be suggested First; statement items need to be reproduced or developed in each dimension. Second; the data used in this study are the results of questionnaires filled out by teachers based on the observations of early childhood in PAUD institutions in two Ex residencies, namely Ex Surakarta Residency and Ex Kedu Residency, so this instrument needs to be developed and tested on a more scale large. Third; scale of the instrument used in this study is a Likert scale with four choices, so it needs to be developed further. Fourth; instrument filling is still done manually, so that subsequent research can be software based.

\section{REFERENCES}

Arifudin, I. (2007). Urgensi implentasi pendidikan multikultural di sekolah. Jurnal Insania.12(2). 
Al-Ghazali, I. (2000). Mengobati penyakit hati membangun akhlak mulia. Alih Bahasa: Muhammad Al-Baqri. Bandung: Karisma.

Al-musanna. (2012). Model pendidikan karakter berbasis kearifan lokal masyarakat. Gayo (Bagian-1) Lintas Gayo On May 28, 2012.

Bekerman, Z., \& Tatar, M. (2009). Parental choice of schools and parents' perceptions of multicultural and co-existence education: the case of the Israeli Palestinian-Jewish bilingual primary schools. European Early Childhood Education Research Journal, 17(2), 171-185. doi:10.1080/13502930902951304.

Berk, E. L. (1989). Child development. Boston: Allyin and Bacon.

Berns, R. M. (2004). Child, family, school, community: Socialization and support. Wadsworth: Thomson.

Browne, M, W., \& Cudeck, R. (1993). Alternative ways of assessing model fit. Sociological Methods \& Research, 21(2), 230-258. doi:10.1177/0049124192021002005.

Çağatay, Ş. M. (2009). The role of school in character education and development according to teachers' views (Unpublished master thesis). Çanakkale Onsekiz Mart University, Çanakkale.

Center for Curriculum Redesign. (2015). Character education for the 21st century: what should students learn? Boston, Massachusetts: Center for Curriculum Redesign.

Fleeson, M., Furr, R. M., Jayawickreme, E., Meindl, P., \& Helzer, E. G. (2014). Character: The prospects for a personality-based perspective morality. Social and Personality Psychology Compass, 8(4) 178-191. https://doi.org/10.1111/spc3.12094.

Lopes, J., Oliveira, C., Reed, L., \& Gable, R. A. (2013). Character education in Portugal. Childhood Education, 89(5), 286-289. doi: 10.1080/00094056.2013.830880.

Ghazali, I., \& Fuad. (2005). Structural equation modeling teori, konsep, dan aplikasi dengan program LISREL 8.54, Semarang: Badan Penerbit Universitas Diponegoro.

Goodman. (2018). Searching for character and the role of schools. Ethics and education.1-21. doi: 10.1080/17449642.2018.1537989.

Hair, J. F., Anderson, R. E., Tatham, R. L., \& Black, W. C. (2010). Multivariate data analysis. New Jersey: Prentice Hall.

Hanum, F. (2009). Pendidikan multikultural sebagai sarana pembentuk karakter bangsa. Makalah. Seminar Regional DIY-Jateng yang Diselenggarakan Himpunan Mahaanak Pendidikan Sosiologi di Universitas Negeri Yogyakarta. Yogyakarta, 14 Desember 2009.

Harun. (2017). Model pendidikan karakter untuk membangun potensi harmoni sosial anak usia dini di di yogyakarta, UNY: Laporan Penelitian.

Hers, R. H., Miller, J. P., \& Fielding, G. D. (1980). Model of moral education: An 
Appraisal. New York: Longman.

Husaini, A. (2015). Membentuk manusia berkarakter dan beradab. Makalah.

Holm, G., \& Londen, M. (2010). The discourse on multicultural education in Finland: Education for whom? Intercultural Education, 21(2), 107-120. doi:10.1080/14675981003696222.

Joreskorg, K., \& Sorbom, D. (2003). Lisrel 8: User's reference guide. Chicago: Scientific Software International.

Kang, S. (2010). Multicultural education and the rights to education of migrant children in south Korea. Educational Review, 62(3), 287-300. doi:10.1080/00131911.2010.503599.

Kementerian Pendidikan Nasional. (2010a). Pendidikan karakter di sekolah menengah peratama, Direktorat Jenderal Manajemen Pendidikan Dasar dan Menengah Direktorat Pembinaan Sekolah Menengah Pertama.

Kementerian Pendidikan Nasional. (2010b. Panduan pendidikan karakter. Jakarta: Kemdiknas.

Khoury, R. (2017). Character education as a bridge from elementary to middle school: a case study of effective practices and processes. International Journal of Teacher Leadership, 8(2), 49-67.

Lerner, R. M. (2017). Character development among youth: Linking lives in time and place. International Journal of Behavioral Development, 42(2), 1-11. doi: 10.1177/0165025417711057.

Lickona, T. (1991). Educating for character: how our school can teach, respect and responsibility. New York: Toronto London Sydney Auckland.

Lickona, T. (1999). Character education: Seven crucial issues. Action in Teacher Education, 20(4), 77-84. doi:10.1080/01626620.1999.10462937.

Matthews, P. W., \& Scott, L. L. (1981). Asian social studies and multicultural education. Asian Stu. Assoc. of Aus. Re, 5(2), 34-40. doi:10.1080/03147538108712176.

Menteri Pendidikan Nasional Republik Indonesia. (2003). Undang-undang republik indonesia nomor 20 tahun 2003 tentang sistem pendidikan nasional beserta penjelasannya. Jakarta: Departemen Pendidikan Nasional.

Nucci, L. (2017). Character: A multi-faceted developmental system. Journal of Character Education, 13(1), 1-16.

Payne, C. (1984). Multicultural education and racism in American schools. Theory into Practice, 23(2), 124-131.doi:10.1080/00405848409543102.

Par, S. Y. (2017). Clarifying the characteristics and exploring the collaboration of citizenship and character education in south Korea. Journal of Social Science Education, 16(3), 22-28. doi: 10.2390/jsse-v16-i3-1600. 
Piland, W. E., \& Barnard, B. (1996). Multicultural education in the classroom. Community College J. of Res. and Prac, 20(1), 49-63. doi:10.1080/1066892960200106.

Pittman, C. T. (2009). Multicultural education and social justice actions. Intercultural Education, 20(2), 173-186. doi:10.1080/14675980902975349.

Schermelleh-Engel, K., Moosbrugger, H., \& Mueler, H. (2003). Evaluating the fit of structural equation models: Tests of significance and descriptive goodness-of-fit measures. Methods of Psychological Research, 8(2), 23-74.

Stedje, L. B. (2010). Nuts and bolts of character education. Edmond, Oklahoma: Character First.

Ugurlu, B. N. (2014). Important values of American and Turkish students. Eurasian J. of Educational Research, 55, 91-108. http://dx.doi.org/ 10.14689/ejer.2014.55.6.

Woodbury, R., \& Lapsley, D. (2016). Moral-character development for teacher education. Ac in Teac. Edu, 38(3), 194-206. http://dx.doi.org/10.1080/01626620.2016.1194785. 